\title{
PENGOLAHAN AIR LIMBAH PABRIK TEMPE DENGAN BIOFILTER
}

\author{
Indah Nurhayati, Pungut AS, dan Sugito *)
}

\begin{abstract}
Abstrak :
Industri tempe Bapak Karipan di Desa Sedenganmijen Kecamatan Krian Kabupaten Sidoarjo Jawa Timur merupakan home industri dengan teknologi yang sangat sederhana. Air limbah yang dihasilkan langsung dibuang ke sungai. Kedaan ini akan sangat mengganggu kesehatan lingkungan sekitar yang pada akhirnya akan mengganggu kesehatan masyarakat pengguna air sungai tersebut. Untuk mengatasi masalah lingkungan di lokasi industri tempe Bapak Karipan, maka tim dosen Teknik Lingkungan Universitas PGRI Adi Buana Surabaya melalukan pengabdian kepada masyarakat melalui program VUCER dari DP2M DIKTI Depdiknas. Program yang dilaksanakan dalam pengabdian kepada masyarakat ini adalah membangun instalasi penglah air limbah (IPAL) dengan proses biofilter di industri tempe $P$. Karipan. Tujuan dari pengadaan IPAL adalah untuk meningkatkan kualitas lingkungan produksi, meningkatkan kualitas produk (tempe) industri tempe sehingga hygienis, meningkatkan kesejahteraan pengusaha mitra dan kenyamanan masyarakat sekitar dari gangguan cemaran akibat proses produksi industri tempe,meningkatkan rasa aman pengusaha mitra dari segala bentuk komplain (protes) masyarakat dan pihak berwenang terkait dengan pencemaran lingkungan akibat limbah cair industri tempe tersebut. Pengabdian masyarakat ini dilakukan dalam tiga tahap. Tahap pertama penyebaran angket, yang bertujuan untuk mengetahui bagaimana dampak air limbah pabrik tempe terhadap lingkungan sekitar. Tahap kedua pembangunan IPAL. Tahap ke tiga penyebaran angket dengan tujuan untuk mengetahui dampak limbah industri tempe terhadap lingkungan sekitar setelah dibangun instalasi pengolah air limbah. Pelaksanaan pegabdian masyarakat di pabrik tempe memberikan hasil sebagai berikut : Sebelum dilakukan pengolahan limbah cair industri tempe menggangu lingkungan sekitar, terutama menyebabkan bau busuk dan pencemaran air sungai, pengolahan limbah industri tempe milik bapak Karipan yang berada di Desa Sedengan Mijen Kecamatan Krian Kabupaten Sidoarjo setelah diolah dengan biofilter diperoleh hasil yang sangat memuaskan dengan efisiensi penurunan rata-rata 98 $\%$, untuk parameter $B O D, C O D$, TSS, sehingga efluen yang dibuang ke sungai sudah memenuhi baku mutu sesuai dengan SK. Gub. Jatim No. 136 tahun 1994, Tentang Baku Mutu Limbah Cair Industri, dengan dibangunnya IPAL untuk mengolah limbah cair industri tempe Bapak Karipan menjadikan lingkungan sekitar industri menjadi lebih baik,pemilik industri tempe merasa aman dari ancaman protes masyarakat terkait karena limbah cair industrinya sudah tidak mengganggu lingkungan sekitar.
\end{abstract}

Kata kunci : IPAL biofilter, limbah cair, industri tempe

\section{PENDAHULUAN}

Tempe merupakan salah satu produk olahan kedelai yang telah dikenal lama di Indonesia terutama di P. Jawa. Jenis makanan ini sangat disukai hampir setiap kalangan masyarakat. Bagi masyarakat Sidoarjo pada khususnya dan Jawa Timur pada umumnya tempe sudah menjadi menu makanan keluarga seharihari, karena tempe merupakan makanan yang mengandung protein tinggi, enak rasanya dan harganya terjangkau oleh semua lapisan masyarakat. Masyarakat Jawa Timur boleh dibilang tiada hari tanpa tempe.
Tempe memiliki kandungan gizi yang cukup tinggi, terutama kandungan proteinnya sekitar $65 \%$ atau setara dengan daging ayam. Selain itu tempe juga mudah dicerna, sehingga produk ini dapat dikonsumsi oleh semua umur, bahkan oleh penderita pencernaan sekalipun.

Industri tempe dapat dilakukan dengan teknologi dan peralatan sederhana, sehingga industri ini banyak tersebar di pulau jawa dan pada umunya merupakan indusri kecil.

\footnotetext{
*) Dosen Teknik Lingkungan

Universitas PGRI Adi Buana Surabaya
} 


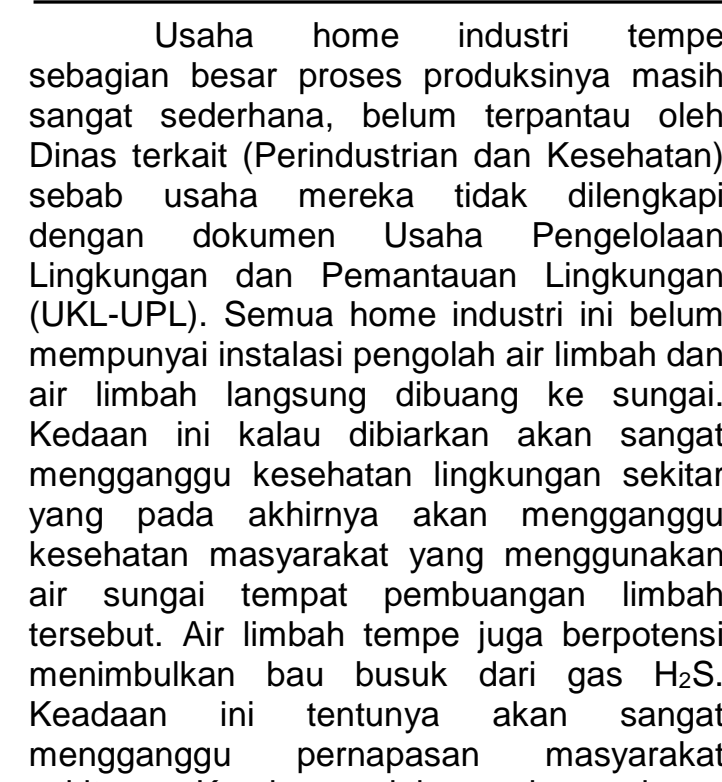
sekitar. Keadaan ini perlu adanya pengolahan air limbah sebelum dibuang ke sungai. Salah satu pengolahan air limbah adalah dengan metode biofilter

Limbah cair industri adalah limbah dalam wujud cair yang dihasilkan oleh kegiatan industri yang dibuang ke lingkungan dan diduga dapat mencemari lingkungan. Berdasarkan SK Gubbernur Jawa Timur No. 136 tahun1994 tentang baku mutu limbah cair industri atau kegiatan usaha lain, disebutkan bahwa baku mutu limbah cair industri tahu dan kecap/tempe adalah sebagai berikut:

- BOD maksimal $75 \mathrm{mg} / \mathrm{l}$

- COD maksimal 200 mg/l

- TSS maksimal $50 \mathrm{mg} / \mathrm{l}$

- $\mathrm{pH}$ antara 6-9

Pada industri pembuatan tempe, sebagian besar limbah cair yang dihasilkan berasal dari lokasi perendaman kedelai, pencucian kedelai, peralatan proses dan lantai. Limbah cair industri tempe sangat khas dengan karakteristik TSS, BOD, COD yang tinggi, $\mathrm{pH}$ asam, bersifat biodegradable (dapat diuraikan oleh mikroorganisme) dan berpotensi menimbulkan bau busuk dari $\mathrm{H}_{2} \mathrm{~S}$.

Hasil tes laboratorium air limbah pembuatan tempe $P$. Karipan menunjukan hasil sebagai berikut:

- $\mathrm{pH}=4,8$

- TSS = $1945 \mathrm{mg} / \mathrm{l}$,

- $\mathrm{COD}=3.102 \mathrm{mg} / \mathrm{L}$

- $\mathrm{BOD}=1.634 \mathrm{mg} / \mathrm{l}$.

Hasil pengamatan secara fisik dan tes laboratorium menunjukan bahwa air limbah dari industri tempe Bapak Karipan belum memenuhi baku mutu limbah cair untuk pabrik tahu dan tempe/kecap seperti yang tertera dalam SK Gub. Jatim No. 136 tahun 1994.

Biofilter merupakan salah satu pengolahan limbah cair secara biologis, proses kerjanya memanfaatkan kehidupan mikroorganisme untuk menguraikan polutan. Penguraian biologis terjadi secara aerob dan anaerob. Dalam penguraian secara biologis diharapkan terjadi proses penguraian secara alamiah untuk membersihkan air sebelum dibuang ke sungai atau badan air.

Bebarapa keunggulan proses pengolahan air limbah dengan biofilter anaerob dan aerob antara lain adalah:

- Pengolahannya sangat sederhana

- Biaya operasi rendah

- Dibandingkan dengan proses lumpur aktif, lumpur yang dihasilkan relatif rendah

- Dapat menghilangkan nitrogen dan pospor yang dapat menyebabkan eutropikasi

- Suplai udara untuk aerasi relatif kecil

- Dapat digunakan untuk air limbah dengan beban BOD yang cukup tinggi

- Dapat menghilangkan padatan tersuspensi (SS) dengan baik. (BPPT. 2006).

Dengan diaplikasikannya teknologi biofilter untuk mengolah limbah cair industri tempe, diharapkan :

- Kualitas efluen limbah cair home industri tempe yang dibuang ke sungai sudah memenuhi baku mutu limbah cair yang ditentukan.

- Kualitas lingkungan internal home industri tempe meningkat sehingga kualitas lingkungan internal terjamin.

- Produk tempe yang dihasilkan menjadi lebih hygienis.

- Untuk meningkatkan rasa aman pengusaha mitra dari segala bentuk kompail (protes) masyarakat dan pihak berwenang terkait dengan pencemaran lingkungan akibat limbah cair industri tempe tersebut.

\section{BAHAN DAN METODE METODE}

Lokasi pengabdian masyarakat di home industri tempe Bapak Karipan Desa Sedenganmijen Kecamatan Krian Kabupaten Sidoarjo Jawa Timur.

Metode yang digunakan untuk memecahkan permasalahan dalam pengabdian masyarakat ini adalah metode penyebaran angket dan teknologi tepat guna berupa pembuatan instalasi pengolah air 
limbah (IPAL) yang disertai dengan eksperimen di lokasi industri. IPAL yang digunakan adalah IPAL dengan teknik biofilter aerob-anaerob. Dengan metode ini air limbah secara alamiah akan diuraikan oleh mikroorganisme anaerob dan aerob sebelum dibuang ke sungai. Tahap-tahap pengolahan limbah cair dengan cara biofilter adalah sebagai berikut :

- Proses fisik sedimentasi yaitu untuk mengendapkan suspended solid (SS)

- Proses anaerobik dan aerobik untuk mendegradasi komponen organik (BOD, COD, amoniak dan pospat dll).

Desain yang digunakan untuk pengolahan air limbah dengan biofilter adalah sebagai berikut:

\section{a. Alat dan bahan}

- Bak sedimentasi

- Volume : kapasitas debit limbah cair yang dihasilkan

- Bentuk : persegi panjang

- Bahan :beton bertulang/pasangan bata dan bertutup dilengkapi lubang kontrol.

- Asesoris: pipa inlet dan outlet secara gravitasi.

- Maintenance : dengan cara pengurasan manual

- Reaktor biofilter anaerobik

Reaktor ini dipasang secara seri terhadap reaktor biofilter aerob

o Ukuran : panjang 2,50m, lebar 1,50 $\mathrm{m}$, kedalaman 1,25 m

- Bahan :beton bertulang dan pasangan bata
- Bentuk :bak persegi tertutup
- Media filter
kerikil
- Model Aliran : upflow
- Waktu tinggal :3 hari

- Reaktor biofilter aerobik
o Ukuran :panjang 2,50 m lebar $\mathrm{m}$

- Bahan :beton bertulang dan pasangan bata

- Bentuk : bak persegi terbuka

- Media filter :kerikil

- Model Aliran :upflow

- Waktu tinggal $: 3$ hari

- Bak pengendap Akhir

Bak pengendap akhir berfungsi sebagai pengendap dan penampung lumpur aktif. Lumpur aktif tersebut dapat diresirkulasi ke bak pengendap awal sesuai dengan kebutuhan. Air limpasan dibuang ke badan air.

b. Prosedur Pelaksanaan

- Perancangan desain IPAL metode biofilter

- Pembuatan bangunan fisik:

- Pembuatan bak sedimentasi

- Pembuatan reaktor biofilter (aerobik dan anaerobik)

- Pengoperasian reaktor biofilter

c. Desain Teknis

Desain teknis dari IPAL biofilter adalah sebagi berikut

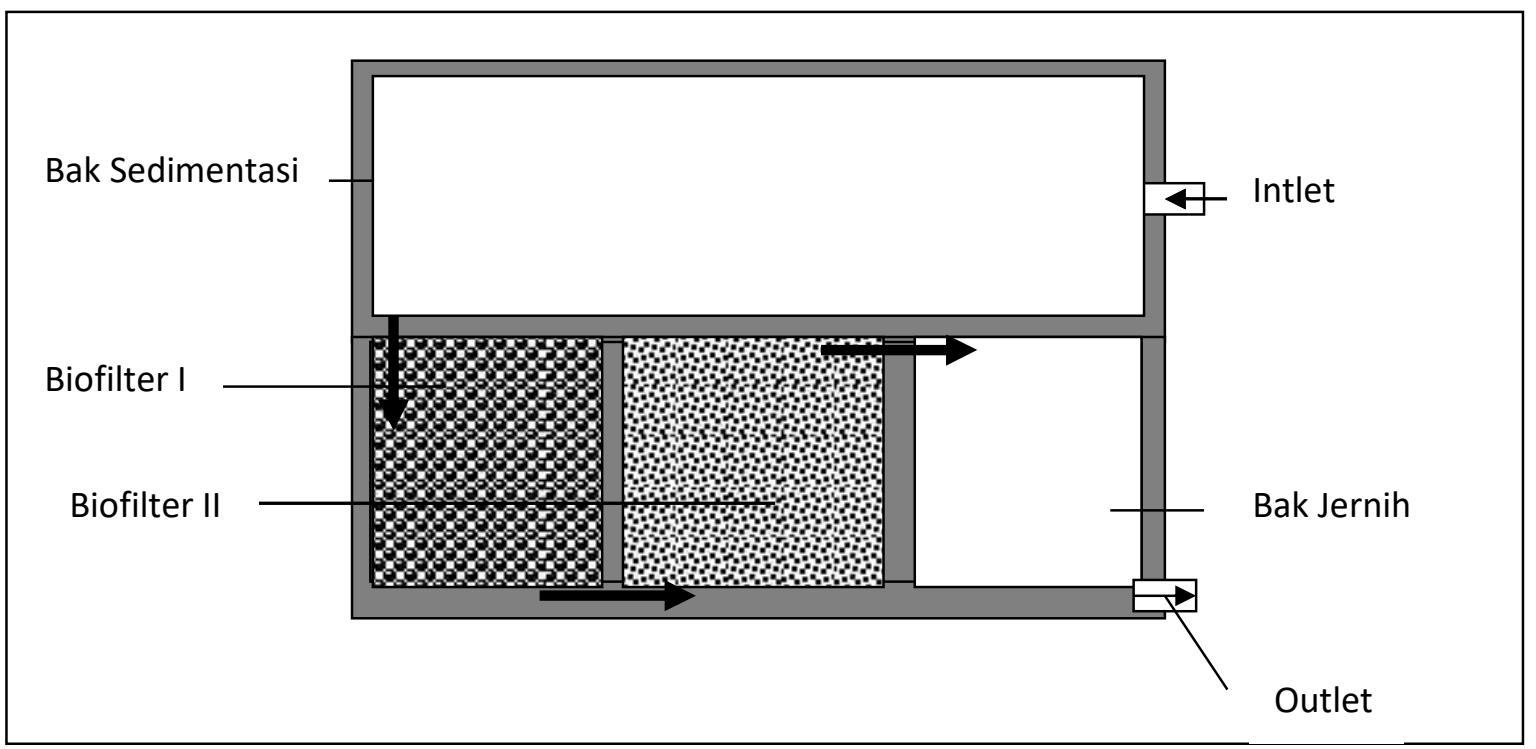

Gambar 1. Layout Bak Sedimentasi dan Reaktor Biofilter 
Tahapan Pelaksanaan Kegiatan Pelaksanaan masyarakat yang bertujuan untuk menyelesaikan masalah pengelolaan lingkungan di sekitar industri pembuatan tempe ini dilakukan dengan melalui beberapa tahap.

Tahap pertama adalah penyebaran angket untuk masyarakat sekitar dan pemilik industri. Pada tahap ini bertujuan untuk mengetahui kualitas lingkungan dan dampak limbah industri tempe terhadap lingkungan sekitar sebelum dibangun instalasi pengolah air limbah (IPAL)

Tahap ke dua adalah pembangunan instalasi pengolah air limbah (IPAL) dengan metode biofilter di lokasi industri pembuatan tempe milik Bapak Karipan. Tahap ini betujuan untuk mengolah air limbah dari industri tempe Bapak Karipan sehingga air limbah tidak mencemari lingkungan sekitar dan kualitas lingkungan sekitar industri tempe menjadi bertambah baik.

Tahap ke tiga adalah penyebaran angket untuk masyarakat sekitar dan pemilik industri. Pada tahap ini bertujuan untuk mengetahui kualitas lingkungan dan dampak limbah industri tempe terhadap lingkungan sekitar setelah dibangun instalasi pengolah air limbah (IPAL).

\section{HASIL DAN PEMBAHASAN}

Pembangunan IPAL untuk mengolah air limbah home industri tempe memberikan hasil sebagai berikut:

Sebelum dilakukan pengolahan Limbah cair industri tempe menggangu lingkungan sekitar, terutama menyebabkan bau busuk dan air sungai menjadi keruh. Keadaan ini disebabkan karena kualitas air limbah industri tempe sangat jelek, beban pencemarnya sangat tinggi. Limbah cair industri tempe sangat khas dengan karakteristik TSS, BOD, COD yang tinggi, $\mathrm{pH}$ asam, bersifat biodegradable (dapat diuraikan oleh mikroorganisme) dan berpotensi menimbulkan bau busuk dari $\mathrm{H}_{2} \mathrm{~S}$.

Air limbah industri tempe milik Bapak Karipan yang berada di Desa Sedengan Mijen Kecamatan Krian Kabupaten Sidoarjo setelah diolah dengan biofilter diperoleh hasil yang sangat memuaskan dengan efisiensi penurunan rata-rata $98 \%$, untuk parameter $\mathrm{BOD}, \mathrm{COD}$, TSS, sehingga efluen yang dibuang ke sungai sudah memenuhi baku mutu sesuai dengan SK. Gub. Jatim No. 136 tahun 1994, tentang Baku Mutu Limbah Cair Industri. Hal ini disebabkan karena IPAL biofilter aerob anaerob proses kerjanya memanfaatkan kehidupan mikroorganisme untuk menguraikan polutan. Penguraian biologis terjadi secara aerob dan anaerob. Dalam penguraian

secara biologis diharapkan terjadi proses penguraian secara alamiah untuk membersihkan air limbah sebelum dibuang ke sungai atau badan air.

Pembangunan IPAL untuk mengolah limbah cair industri tempe Bapak Karipan menjadikan lingkungan sekitar industri menjadi lebih baik. Sebelum dibangun IPAL, air limbah dari proses industri tempe langsung dibuang ke sungai yang berada di depan lokasi industri. Keadaan ini sangat menggangu lingkungan baik ditinjau dari segi kesehatan lingkungan dan dari segi estetika. Hal ini dikarenakan limbah cair industri tempe kadar suspended solidnya tinggi sehingga keruh dan berwarna keputihan, selain itu air limbah juga sangat berpotensi menimbulkan bau yang tidak sedap dari gas $\mathrm{H}_{2} \mathrm{~S}$. Setelah dibangun IPAL, air limbah diolah terlebih dahulu sehingga air limbah yang dibuang ke sungai sudah berwarna jernih dan tidak menimbulkan bau yang tidak sedap. Dengan demikian lingkungan sekitar menjadi bersih, air sungainya tidak keruh dan tidak berbau.

Pemilik industri tempe merasa aman dari ancaman protes masyarakat dan dinas terkait karena limbah cair industrinya sudah tidak mengganggu lingkungan. Sebelum dibangun IPAL home industri pernah diprotes masyarakat sekitar karena lingkungan sekitar tidak bersih, air sungai keruh dan timbul bau tidak sedap. Setelah dibangun IPAL lingkungan sekitar menjadi bersih dan tidak berbau, sehingga pemilik home industri menjadi aman dari ancaman protes warga sekitar.

Dengan dibangunya IPAL maka diharapkan dapat menjadi contoh home induatri tempe lainnya karena memberikan dampak yang sangat besar dalam pengelolaan lingkungan dan dapat menghasilkan produk yang lebih hygienis.

\section{KESIMPULAN}

Berdasarkan hasil pengabdian masyarakat dapat diambil kesimpulan bahwa dengan dibangunya IPAL biofilter untuk mengolah air limbah pabrik tempe $P$. Karipan dapat :

1. Meningkatkan kualitas lingkungan produksi

2. Meningkatkan kualitas produk (tempe) dari segi kesehatannya (hygienis). 
3. Meningkatkan kesejahteraan pengusaha mitra dan masyarakat sekitar dari gangguan cemaran air, tanah dan bau akibat dari proses produksi.

4. Meningkatkan rasa aman pengusaha mitra dari segala bentuk komplain (protes) masyarakat dan pihak berwenang terkait dengan pencemaran lingkungan akibat limbah cair industri tempe tersebut

\section{UCAPAN TERIMA KASIH}

Segala Puji dan syukur penulis panjatkan kehadirat Allah SWT, yang telah memberikan rahmat, hidayah serta ridlhonya, sehingga pengabdian kepada masyarakat program VUCER yang berjudul Penerapan Instalasi Pengolah Air Limbah (IPAL) Biofilter Untuk Meningkatkan Kualitas Efluen Limbah Cair Industri Tempe di Desa Sedenganmijen Krian Kab. Sidoarjo dapat terselesaikan.

PPM Program VUCER ini terselenggara berkat pendanaan DP2M DIKTI dengan nomor SPPH No.

125/SP2H/PPM/DP2M/II/2008.

Dengan terselesaikannya program VUCER ini disampaikan ucapan terima kasih kepada:

1. Direktur Pembinaan penelitian dan Pengabdian Kepada Masyarakat DIRJEN DIKTI DEPDIKNAS, yang telah membiayai pengabdian Kepada masyarakat program VUCER ini.

2. Rektor Universitas PGRI Adi Buana Surabaya

3. Kepala LP2M Universitas PGRI Adi Buana Surabaya

4. Dekan Fakultas Teknik Sipil dan Perencanaan Universitas PGRI Adi Buana

Surabaya

5. Teman-teman dosen di Teknik Lingkunan Universitas PGRI Adi Buana Surabaya

Semoga Allah SWT senatiasa melimpahkan Rahmat dan Hidayahnya kepada kita semua

\section{DAFTAR PUSTAKA}

APHA., 1998. Standart Method For The Examination of Water and Wastewater, $20^{\text {th }}$ edition, Washington.

BPPT., 2006. Teknologi Pengolahan Limbah Cair Sistem Biakan Melekat ( Rumah Sakit,Domestik, Industri).

Metcalf and Eddy. 2003. Watewater Engginering. Mc. Graw-Hill.

Potter, Clifton, dkk., 1994. Limbah Cair Berbagai Industri Di Indonesia, Sumber Pengendalian Dan Bahan Baku. EMDI.

Siregar, S.A. 2005. Instalasi Pengolahan Air Limbah. Knisius, Yogyakarta.

SK. Gub. Jatim No. 136 tahun 1994, Tentang Baku Mutu Limbah Cair Industri

Talib, Suhaimi Abdul. 2004. Sewer Network as Bioreaktor - Integrated Wastewater Treatment System, UTM Malaysia 